Europ. Neurol. 1970;4:128

\title{
Varia
}

Fourth International Symposium on 'The Impedance Methods in Neurology'

The 4th International Symposium on 'The Impedance Methods in Neurology' will be held in Rimini (Italy), September 22-24, 1971. The members of the organizing committee are: N. GeYER, Graz; H. LECHNER, Graz; E. LugARESI, Bologna; S. MARKovich, Miami; F. MARTin, Geneva.

The main themes of the symposium are: (1) Development of Impedance Methods: (a) technical development, (b) recording technique; (2) the Biological Basis of the Impedance Changes: (a) depending on circulation, (b) circulation-independent factors; (3) the possibilities for Differentiation between Intra- and Extracranial Impedance Changes; (4) Clinical Application and their Correlation to Other Methods. Secretary: Dr. P. PAZZAGLia and Dr. L. SABATTINI, Clinica Neurologica delFUni-versita, Via U. Foscolo 7, 40123 Bologna (Italy).

\section{The Neurological Society of India}

The 3rd Asian and Oceanian Congress of Neurology will be held in Bombay during the week 29th November to 5th December 1971. The subjects chosen for the symposia on this occasion are: (i) Stereotaxy and Electrophysiological Advances in Neurology; (ii) Familial and Genetic Disorders of the Nervous System; (iii) Neuropharmacology and Uses of New Drugs in Neurology; (iv) Vascular Disorders of the Central Nervous System; (v) Nutritional and Other Tropical Disorders of the Nervous System.

\section{The International Glossary of Anticonvulsants}

The Epilepsy Literature Project, under the sponsorship of the International Bureau and the International League against Epilepsy, has been compiling an International Glossary of Anticonvulsants. Registrants at the World Congress of Neurological Sciences in New York in September, 1969, received a preliminary edition.

Copies of the Glossary are available at no charge and may be obtained by request to: Mrs. ELLEN R. GRASS, President, International Bureau for Epilepsy, 77 Reservoir Road, Quincy, MA 02170 (USA).

It will be much appreciated if the readers will tell us of any omissions or errors in the Glossary so future editions can be revised. 